CASSOWARY - Volume 1 (2): 121 - 132

ISSN : 2614-8900

E-ISSN : 2622-6545

CProgram Pascasarjana Universitas Papua, https://pasca.unipa.ac.id/

\title{
PERBANYAKAN BEBERAPA JENIS ANGGREK MELALUI TEKNIK KULTUR JARINGAN DAN ANALISIS KEANEKARAGAMAN GENETIK BERDASARKAN PENANDA RAPD
}

\author{
Propagation of several orchid types through tissue culture technique and genetic \\ diversity analysis based on RAPD marker
}

\author{
Gasper Gaman, Nouke Lenda Mawikere*, Barahima Abbas \\ Prodi Magister Ilmu Pertanian, Program Pascasarjana UNIPA \\ Jalan Gunung Salju Amban, Manokwari, Kodepos 98314, Papua Barat
}

* Email: lenda_mawikere@yahoo.com

\begin{abstract}
Papua is the habitat of a variety of orchids and several of orchid species are endemic in Papua. Diversity of orchid species in Papua is a natural resource which needs special attention in conservation efforts and cultivation. The aimes of this research were determined the suitable medium for in vitro propagation technique of several orchid species which endemic in Papua and determine the genetic diversity of five orchids species using RAPD markers. The research was carried out by cultivation of five edemism orchid species on MS medium which enriched 0 to $40 \%$ coconut water. Genetic diversities of five orchid species were determined by using RAPD markers. Results of research showed that overall of orchid were cultured can grow to planlet formation. The suitable medium for growing orchids based on this experiment was Murashige and Skoog (MS) medium that enriched with $40 \%$ coconut water. Molecular analysis using RAPD markers showed that the five species of Papua orchid were tested different from another. UPGMA grouping based on the polymorphic bands show that the five species of orchid studied were devided into three groups on the coefficient of 0.4 or $40 \%$ their genomic different.
\end{abstract}

Keyword: Orchids, Tissue culture, Genetic diversity, RAPD marker.

\begin{abstract}
ABSTRAK: Papua merupakan habitat dari berbagai macam anggrek dan beberapa spesies merupakan endemik Papua. Keragaman jenis tanaman anggrek di Papua merupakan sumber daya alam yang perlu mendapat perhatian dalam upaya konservasi dan budidayanya. Penelitian ini bertujuan menentukan komposisi media yang sesuai untuk pertumbuhan beberapa jenis anggrek endemik Papua melalui kultur in vitro dan menentukan keragaman genetik dengan menggunakan penanda molekuler RAPD. Penelitian ini dilakukan dengan mengkulturkan lima jenis anggrek endemik Papua pada media MS yang diperkaya dengan air kelapa $0-40 \%$. Keragaman genetik ke lima jenis anggrek yang diteliti ditentukan dengan menggunakan penanda RAPD. Hasil penelitian menunjukkan bahwa dari lima jenis anggrek yang dikulturkan semuanya dapat tumbuh membentuk planlet. Perlakuan terbaik adalah media MS yang diperkaya dengan air kelapa 40\%. Hasil analisis molekuler dengan menggunakan penanda RAPD
\end{abstract}


menunjukkan bahwa dari lima jenis anggrek endemik Papua yang diuji berbeda antara satu dengan lainnya. Hasil pengelompokan UPGMA berdasarkan pola pita DNA polimorfik menunjukkan bahwa dari lima species anggrek yang diteliti membentuk tiga kelompok pada koefisien 0.4 atau $40 \%$ genomnya berbeda.

Kata Kunci: Anggrek, kultur jaringan, keanekaragaman genetik, penanda RAPD

\section{PENDAHULUAN}

Anggrek (Dendrobium sp) merupakan salah satu tanaman yang memiliki keindahan bunga yang beranekaragam bentuk dan warna. Tanaman ini dengan segala keunikannya menarik perhatian banyak orang. Anggrek memiliki prospek yang cerah untuk dikembangkan dimasa mendatang karena harganya yang relatif memuaskan (Rukmana, 2000).

Jumlah tanaman anggrek yang telah diketahui di seluruh dunia sekitar 20.000-35.000 spesies. Kurang lebih 5.000 spesies diantaranya berada di Indonesia. Spesies tersebut dilaporkan banyak dijumpai di Kepulauan Maluku dan Papua. Jumlah spesies itu sampai sekarang belum dapat diketahui dengan pasti (Darmono, 2004). Ketua Perhimpunan Anggrek Indonesia (PAI) mengungkapkan bahwa terdapat 2.770 species anggrek di Papua dan 300 species yang sudah diidentifikasi oleh World Wide Fund for Nature (WWF) (Noertjahyo, 2002). Papua merupakan habitat dari berbagai macam tumbuhan. Hal yang menakjubkan bagi para ilmuan adalah kebanyakan dari spesies tumbuhan ini merupakan endemik Papua, yang tidak ditemukan di tempat lain (Muller, 2005).

Dalam upaya konservasi untuk melestarikan anggrek endemik Papua, maka upaya perbanyakan tanaman anggrek perlu dilakukan. Teknologi perkembangbiakkan tanaman perlu dikembangkan untuk mempertahankan ketersediaan sumber daya alam (Kalimuthu et al., 2007). Salah satu teknologi yang dikembangkan sekarang adalah teknik kultur jaringan. Teknik kultur jaringan mampu menyediakan bibit dalam jumlah banyak dan cepat serta mampu menumbuhkan tanaman yang sulit atau tidak dapat dikembangkan secara konvensional (Pierik, 1987).

Perbanyakan anggrek menggunakan biji sangat sulit dilakukan dengan cara konvensional, tetapi dengan metode kultur jaringan sekitar 99\% dari jutaan biji yang terdapat dalam satu kapsul dapat ditumbuhkan, jika berada pada kondisi media yang sesuai. Tiap spesies anggrek memiliki formulasi media yang berbeda untuk dapat tumbuh secara maksimal. Penelitian ini dilakukan untuk menentukan air kelapa pada media MS yang tepat untuk pertumbuhan biji anggrek sehingga dapat membentuk planlet. Tanaman anggrek yang dihasilkan melalui teknik kultur in vitro akan dianalisis secara molekuler dengan menggunakan Random Amplified Polymorphic DNA (RAPD) untuk menentukan keanekaragamannya. Metode RAPD dapat digunakan untuk menentukan keanekaragaman anggrek hasil perbanyakan in vitro (Sulistianingsih et al., 2004). RAPD merupakan salah satu penanda DNA menggunakan prinsip kerja mesin PCR, yang mampu mengaplifikasi sekuen DNA tertentu secara in vitro (Mawikere, et al., 2007).

\section{BAHAN DAN METODE}

Penelitian ini terdiri atas dua kegiatan yaitu, perbanyakan beberapa jenis anggrek melalui teknik kultur 
jaringan dan analisis keanekaragaman genetik berdasarkan penada RAPD.

\section{Perbanyakan Anggrek Secara In Vitro.}

Penelitian berlangsung selama 5 bulan dan bertempat di Laboratorium Bioteknologi Fapertek Unipa Manokwari. Bahan yang digunakan dalam penelitian antara lain: lima jenis tanaman anggrek endemik Papua, larutan air kelapa, alkohol, spirtus, agar-agar, sukrosa, $\mathrm{NaOH}, \mathrm{HCl}$, sabun cuci, aquades. Bahan kimia yang digunakan adalah $\mathrm{NH}_{4} \mathrm{NO}_{3}, \quad \mathrm{KNO}_{3}, \mathrm{CaCl}_{2} .2 \mathrm{H}_{2} \mathrm{O}$, $\mathrm{MgSO}_{4} .7 \mathrm{H}_{2} \mathrm{O}, \mathrm{KH}_{2} \mathrm{PO}_{4}, \mathrm{FeSO}_{4} .7 \mathrm{H}_{2} \mathrm{O}$, $\mathrm{Na}_{2}$ EDTA, $\mathrm{MnSO}_{4} .4 \mathrm{H}_{2} \mathrm{O}, \mathrm{ZnSO}_{4} .7 \mathrm{H}_{2} \mathrm{O}$, $\mathrm{H}_{3} \mathrm{BO}_{3}, \mathrm{KI}, \mathrm{Na}_{2} \mathrm{MoO}_{4} .2 \mathrm{H}_{2} \mathrm{O}, \mathrm{CuSO}_{4}$. $5 \mathrm{H}_{2} \mathrm{O}, \mathrm{CoCl}_{2} \cdot 6 \mathrm{H}_{2} \mathrm{O}$, Myo-inositol, Niacin, Pyridoxine- $\mathrm{HCl}$, Thiamine- $\mathrm{HCl}$ dan Glycine. Alat-alat yang digunakan adalah gelas piala berbagai ukuran, laminar air flow cabinet, pipet bersama tabungnya, pinset berbagai ukuran, pemanas listrik, botol gelap, tissue, pengaduk kaca, $\mathrm{pH}$ meter, plastik, autoclave, freezer, ruang $\mathrm{AC}$, serbet, petridish, timbangan analitik, lampu spirtus, skalpel, gunting, penggaris, labu ukur, gelas kultur dan kamera.

Penelitian dilakukan dengan menggunakan Rancangan Acak Lengkap (RAL) dua faktor perlakuan. Faktor pertama adalah lima jenis anggrek yaitu; D. merbelianum tipe $1, D$. merbelianum tipe 2, Dendrobium sp, D. discolor dan D. lineale. Faktor kedua yaitu media MS yang diperkaya air kelapa $0 \%, 10 \%$, 20\%, 30\% dan 40\%. Masing-masing perlakuan diulang sebanyak tiga kali sehingga seluruhnya terdapat 75 satuan percobaan. Kegiatan penelitian meliputi: 1) Sterilisasi alat, 2) persiapan eksplan, 3) pembuatan media tumbuh, 3) sterilisasi media tumbuh, 4) penanaman eksplan pada media tumbuh, 5) pengamatan hasil, dan 6) pengolahan data. Data yang diperoleh dianalisis meng- gunakan analisis ragam dan jika berbeda nyata dilanjutkan dengan uji Beda Nyata Jujur (BNJ).

\section{Analisis Keanekaragaman Genetik Berdasarkan Penanda RAPD.}

Penelitian analisis keanekaragaman genetik dilaksanakan selama 2 bulan, bertempat di Laboratorium Biomolekuler Unipa Manokwari. Bahan yang digunakan adalah tanaman anggrek sebanyak 5 jenis, 5 jenis primer RAPD, alkohol, es batu, tissue, buffer AP 1 buffer AP 2, Rnase, DNeasy Plant Mini Kit", buffer AP 3/E, ethanol 96$100 \%$, buffer AW. Alat-alat yang digunakan adalah mortal, freezer, ruang AC, serbet, timbangan analitik, gunting, vortex, ependorf (mini tube), sentrifius, pipet, micro tubi $2 \mathrm{ml}$ dan lain-lain.

Tahapan penelitian meliputi: 1) persiapan 5 jenis anggrek hasil penelitian tahap pertama, 2) isolasi DNA 5 jenis anggrek menggunakan DNeasy Plant Mini Kit, 3) Amplifikasi PCR menggunakan 5 primer decamer RAPD primer, yaitu OPA1 (5'-CAGGCCCT TC-3'), OPA4 (5'-AATCGGGCTG-3'), OPA12 (5'-TCGGCGATAG-3'), OPA 14 (5'-TCTGTGCTGG-3'), dan OPU3 (5'-CTATGCCGAC-3'), 4) visualisasi pita DNA menggunakan UV eliminator, dan 5) identifikasi polimorfisme pita DNA .

Analisis data dilakukan menggunakan analisis multivarian. Data karakterisasi adalah data biner berdasarkan profil pita DNA yang muncul pada gel. Pita DNA akan diberi nilai 1 jika ada pita DNA dan yang tidak memiliki pita diberi nilai 0 . Analisis koefisien ketidakmiripan karakter DNA berdasarkan matriks ketidakmiripan genetik dan pembuatan dendrogram dilakukan dengan metode UPGMA (Unweighted Pair-Group Method Arithmetic) pada program NTSYS (Numerical Taxonomy and Multivariate System) versi pc 2.02. 


\section{HASIL DAN PEMBAHASAN}

\section{Anggrek Endemik Papua.}

Penampilan lima jenis anggrek endemik Papua yang dikulturkan dan digunakan untuk analisis DNA pada penelitian ini disajikan pada Gambar 1.

Alam Papua memiliki sumber daya alam yang unik dan menarik, diantaranya adalah tanaman anggrek yang sebagian besar ditemukan tumbuh liar di hutan. Kemampuan masyarakat untuk mengembangbiakkan anggrek di Papua masih sangat terbatas, sehingga jenis-jenis anggrek yang dipelihara oleh masyarakat sangat sulit untuk dipertahankan potensinya.
Jenis-jenis anggrek ini masih sangat sulit untuk mendapatkan bibitnya di alam dan diperkirakan akan punah bila tidak ada upaya perbanyakan secara profesional. Sampai saat ini masyarakat di Papua masih kesulitan untuk perbanyakan bibit anggrek dalam jumlah yang banyak untuk memenuhi permintaan konsumen. Salah satu alternatif perbanyakan anggrek adalah melalui kultur jaringan atau kultur in vitro. Zulkarnain (2009) mengungkapkan bahwa teknik kultur in vitro bermanfaat dalam perbanyakan klon secara cepat dan perbanyakan tanaman yang sulit diperbanyak secara konvensional.
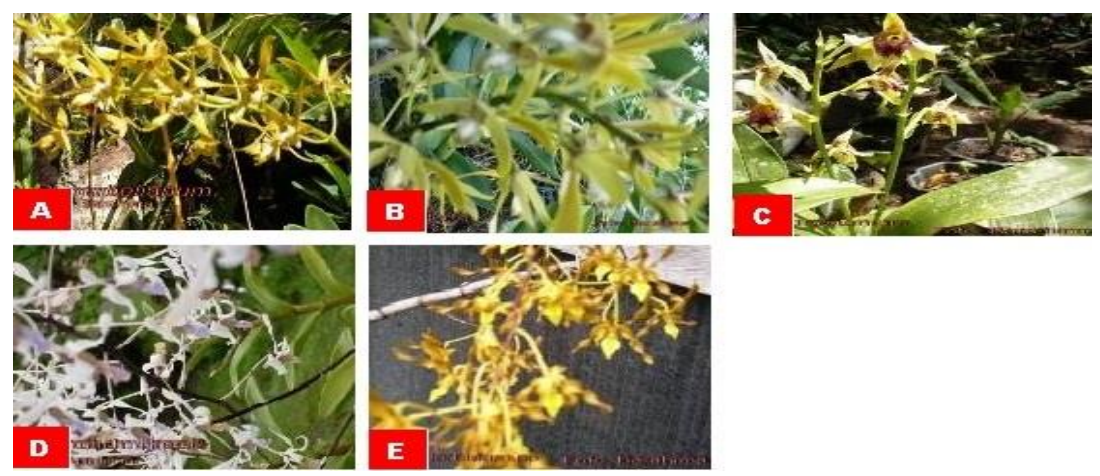

Gambar 1. Penampilan jenis-jenis anggrek yang diteliti: D. merbelianum-1 (A),

D. merbelianum-2 (B), Dendrobium sp (C), D. discolor (D), dan D. lineale (E)

\section{Kultur In Vitro Anggrek.}

Ukuran dan bentuk biji anggrek endemik Papua yag dijadikan sebagai bahan eksplan pada kultur in vitro disajikan pada Gambar 2.

Proses pengkulturan tanaman anggrek dimulai dari biji. Di dalam satu buah anggrek terdapat ribuan sampai jutaan biji. Biji-biji ini akan tumbuh dengan baik apabila dikulturkan pada media tumbuh yang sesuai di dalam laboratorium. Proses pertumbuhan biji anggrek dalam kultur dimulai dari awal pengkulturan sampai terjadi perubahan penampilan.

Perubahan awal dalam proses pertumbuhan biji anggrek yaitu terjadi perubahan warna dari eksplan biji yang dikulturkan. Warna awal biji anggrek yang telah memasuki fase fisiologis dari semua spesies yang diamati, yaitu warna kuning terang. Pertumbuhan higroskopis anggrek membentuk fase globular seperti terlihat pada Gambar 2C. Dari lima jenis anggrek yang telah dikulturkan semuanya berhasil membentuk globular.

Tahapan pertumbuhan dan perkembangan biji anggrek sesudah membentuk struktur globular yaitu membentuk struktur protocorm (Gambar 2E). Spesies-spesies anggrek endemik Papua yang dikulturkan tumbuh dan berkembang dengan baik dalam membentuk protocorm pada media MS yang diperkaya dengan air 
kelapa. Pada umumnya media MS yang diperkaya dengan air kelapa dapat menginduksi pertumbuhan biji anggrek membentuk protocorm.

Gambar 3 memperlihatkan lima jenis anggrek endemik Papua pada fase pertumbuhan planlet. Waktu yang diperlukan untuk biji anggrek sampai pada fase planlet adalah 3 bulan. Setelah fase ini, planlet dipindahkan ke dalam masing-masing media kultur sesuai perlakuan dan diletakkan di ruang kultur.
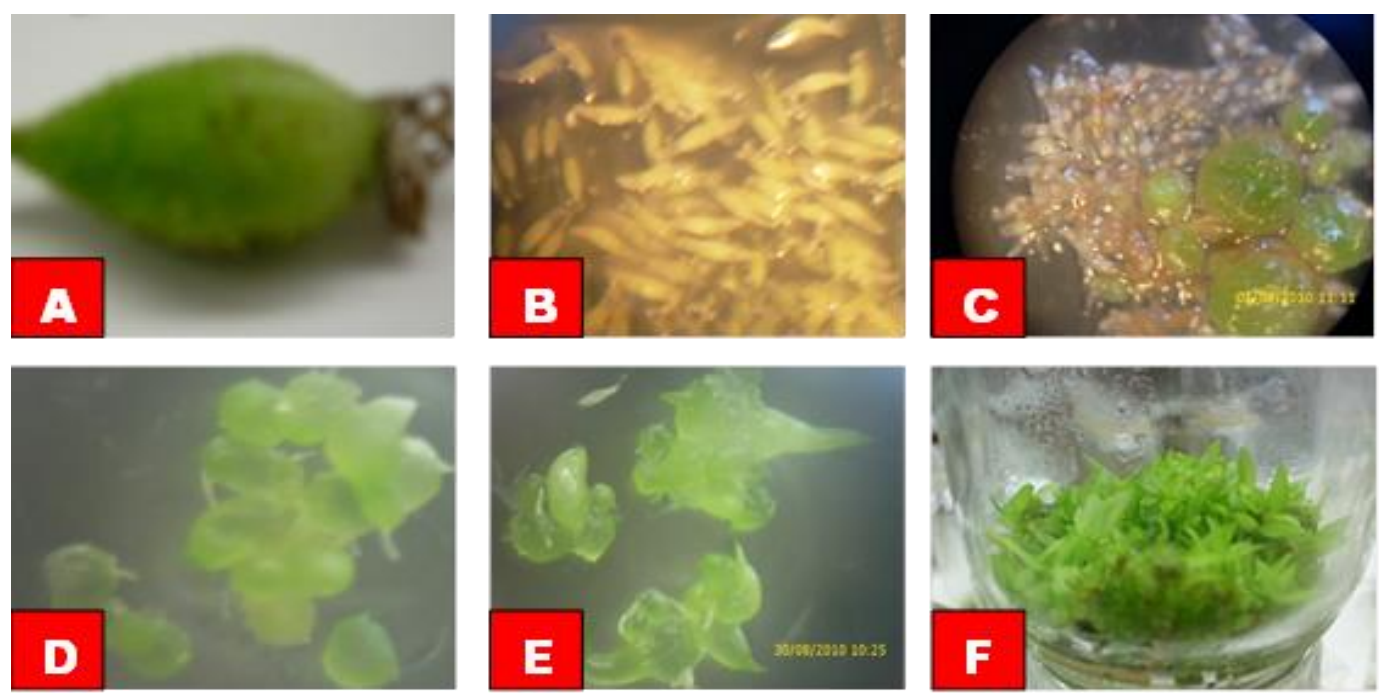

Gambar 2. Pertumbuhan dan perkembangan biji anggrek secara in vitro. Buah anggrek (A), Biji anggrek dengan pembesaran $100 \mathrm{kali}$ (B), Inisiasi fase pembentukan globular dengan pembesaran 100 kali (C), Fase pembentukan globular dengan pembesaran 100 kali (D), Fase pembentukan protocorm dengan pembesaran 100 kali (E), dan Fase pembentukan planlet (F).
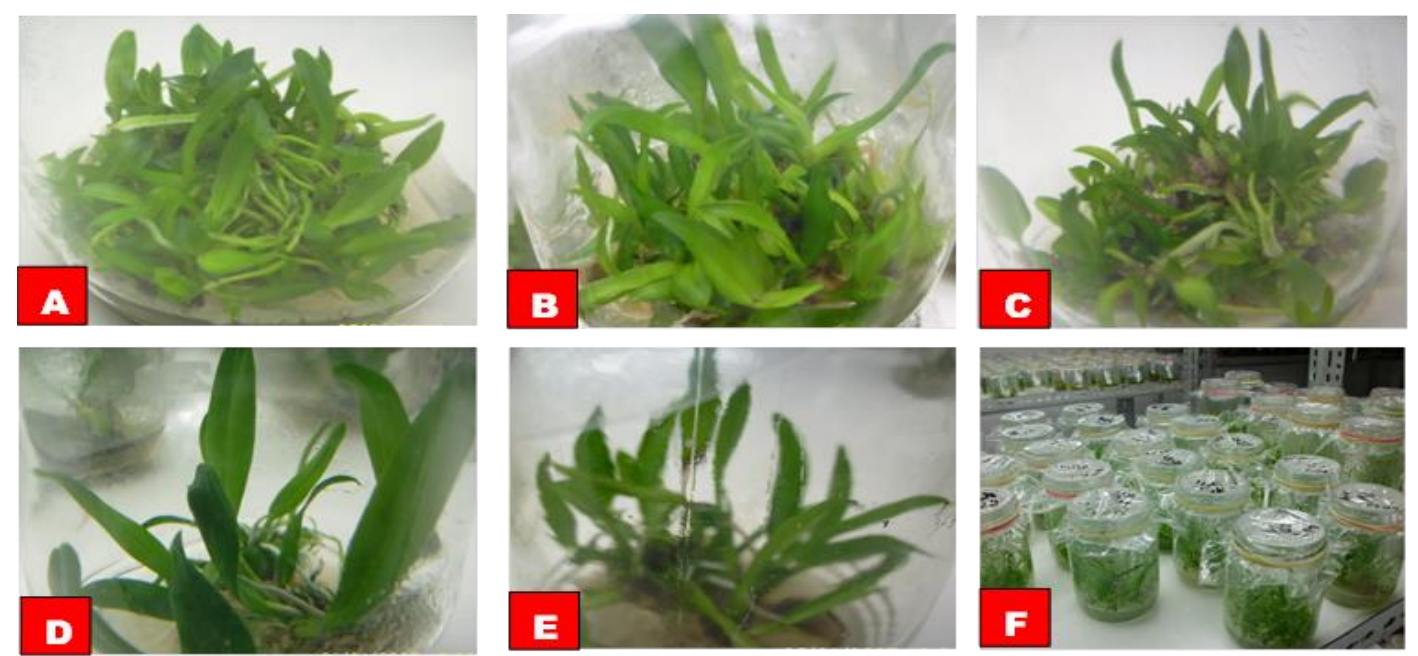

Gambar 3. Pertumbuhan beberapa jenis anggrek endemik Papua yang dikultur secara in vitro sampai pada fase pertumbuhan planlet: Merbelianum tipe-1 (A), Merbelianum tipe-2 (B), Dendrobium sp (C), Dendrobium discolor (D), Dendrobium lineale (E), dan Penampilan pertumbuhan di rak kultur (F) 
CASSOWARY - Volume 1 (2): 121 - 132

ISSN : 2614-8900

E-ISSN : 2622-6545

CProgram Pascasarjana Universitas Papua, https://pasca.unipa.ac.id/

Data karakter-karakter yang diamati dari lima jenis tanaman anggrek endemik Papua yang dikombinasikan terhadap lima perlakuan media tanam (MS0, MS10, MS20, MS30, dan MS40) pada kultur in vitro dapat dilihat pada Tabel 1-4.

Jumlah daun tertinggi untuk masing-masing jenis anggrek terdapat pada perlakuan media MS40, namun secara keseluruhan anggrek $D$. lineala (MS40) memiliki jumlah daun terbanyak (8 daun). Media kultur tanpa penambahan air kelapa (MS0) menunjukkan memiliki rata-rata jumlah daun paling sedikit (Tabel 1). Dari hasil penelitian ini diperoleh bahwa media tumbuh yang digunakan dapat menginisiasi pembentukan daun dan penambahan larutan air kelapa pada media kultur dapat meningkatkan jumlah daun untuk semua jenis tanaman anggrek. Penelitian George dan Sherrington (1984) mendapatkan bahwa penambahan air kelapa dapat meningkatkan partumbuhan jaringan yan dikulturkan seperti mendorong pertumbuhan kalus dan terjadinya morfogenesis. Menurut Santoso (2003) bahwa air kelapa mengandung mineral dan vitamin. Mineral yang terkandung dalam air kelapa yaitu $\mathrm{K}$, $\mathrm{Na}, \mathrm{Ca}, \mathrm{Mg}, \mathrm{Fe}, \mathrm{Cu}, \mathrm{P}$ dan S. Unsurunsur yang terkandung dalam mineral ini dapat membantu/memicu proses perkembangan pada daun tanaman. Hasil pertumbuhan tanaman dalam teknik kultur in vitro didasarkan oleh teori totipotensi, yaitu kemampuan setiap sel, dari mana saja sel tersebut diambil, apabila diletakan dalam lingkungan yang sesuai akan dapat tumbuh menjadi tanaman yang sempurna (Suryowinoto, 1991).

Tabel 2 menunjukkan bahwa setiap penambahan larutan air kelapa pada media kultur dapat meningkatkan jumlah akar pada semua jenis tanaman anggrek. Jumlah akar terbanyak terdapat pada perlakuan media MS40, walaupun pada perlakun MS30 terdapat 3 jenis anggrek (D. merbelianum (tipe 1), Dendrobium sp, dan $D$. lineale) yang memiliki rata-rata jumlah akar sama seperti perlakuan MS40 (6.33 akar). D. discolor (MS40) memiliki jumlah akar terbanyak (7 akar), sedangkan $D$. merbelianum (tipe 2) pada media MS0 memiliki jumlah akar paling sedikit (4.67 akar). Kondisi ini disebabkan oleh kandungan nutrisi dalam air kelapa yang memacu proses pertumbuhan dan jumlah akar pada setiap media perlakuan, sehingga di dalam setiap penambahan air kelapa terdapat penambahan jumlah akar. Menurut penelitian yang dilakukan oleh Wospakrik (2008), pemberian air kelapa memberikan partumbuhan yang baik pada jumlah daun, tinggi tanaman, jumlah akar, dan panjang akar. Selain itu, kemampuan tanaman untuk melakukan regenerasi sangat bervariasi antara satu jenis dengan jenis yang lain (Abbas, 2011).

Tabel 1. Rata-rata jumlah daun tanaman pada saat akhir pengamatan

\begin{tabular}{lccccc}
\hline \multicolumn{1}{c}{ Jenis Anggrek } & MS0 & MS10 & MS20 & MS30 & MS40 \\
\hline D. merbelianum -1 & 5.00 & 5.33 & 5.67 & 5.67 & 6.00 \\
D. merbelianum -2 & 4.67 & 5.33 & 5.33 & 6.00 & 6.33 \\
Dendrobium sp & 6.00 & 6.00 & 6.33 & 7.00 & 7.00 \\
D. discolor & 5.67 & 5.67 & 5.67 & 6.00 & 6.33 \\
D. lineale & 6.33 & 7.00 & 6.67 & 7.33 & 8.00 \\
\hline
\end{tabular}


Tabel 2. Rata-rata jumlah akar tanaman pada saat akhir pengamatan

\begin{tabular}{lccccc}
\hline \multicolumn{1}{c}{ Jenis Anggrek } & MS0 & MS10 & MS20 & MS30 & MS40 \\
\hline D. merbelianum (tipe 1) & 5.67 & 5.33 & 5.67 & 6.33 & 6.67 \\
D. merbelianum (tipe 2) & 4.67 & 5.33 & 5.33 & 5.33 & 5.67 \\
Dendrobium sp & 5.67 & 6.00 & 6.33 & 6.33 & 6.67 \\
D. discolor & 5.33 & 5.67 & 5.67 & 6.00 & 7.00 \\
D. lineale & 5.33 & 5.33 & 5.67 & 6.33 & 6.33 \\
\hline
\end{tabular}

Tabel 3. Rata-rata panjang daun tanaman pada akhir pengamatan $(\mathrm{cm})$

\begin{tabular}{lccccc}
\hline \multicolumn{1}{c}{ Jenis Anggrek } & MS0 & MS10 & MS20 & MS30 & MS40 \\
\hline D. merbelianum (tipe 1) & 4.33 & 5.00 & 5.33 & 6.00 & 6.33 \\
D. merbelianum (tipe 2) & 4.67 & 5.00 & 5.67 & 5.67 & 6.67 \\
Dendrobium sp & 5.33 & 5.67 & 6.00 & 5.67 & 7.33 \\
D. discolor & 4.00 & 4.67 & 5.00 & 5.67 & 6.00 \\
D. lineale & 4.67 & 4.67 & 5.67 & 5.67 & 6.33 \\
\hline
\end{tabular}

Tabel 4. Rata-rata panjang akar tanaman pada saat akhir pengamatan $(\mathrm{cm})$

\begin{tabular}{lccccc}
\hline \multicolumn{1}{c}{ Jenis Anggrek } & MS0 & MS10 & MS20 & MS30 & MS40 \\
\hline D. merbelianum (tipe 1) & 4.00 & 4.33 & 4.67 & 5.33 & 5.67 \\
D. merbelianum (tipe 2) & 4.33 & 4.67 & 5.00 & 5.00 & 6.33 \\
Dendrobium sp & 6.00 & 5.67 & 6.33 & 6.67 & 6.67 \\
D. discolor & 4.33 & 4.33 & 4.67 & 5.33 & 5.33 \\
D. lineale & 5.00 & 5.33 & 6.33 & 6.00 & 6.67 \\
\hline
\end{tabular}

Tabel 3 menunjukkan bahwa setiap penambahan larutan air kelapa pada media kultur dapat meningkatkan panjang daun pada semua jenis tanaman anggrek. Rata-rata panjang daun tertinggi terdapat pada perlakuan media MS40 dan Dendrobium sp memiliki panjang daun terpanjang $(7.33 \mathrm{~cm})$. Kelima jenis anggrek memiliki rata-rata panjang daun terpendek pada media kultur MS0. Hasil ini menunjukkan bahwa Dendrobium sp lebih tanggap dalam menyerap hara pada media tumbuh yang diperkaya dengan penambahan larutan air kelapa dalam menginisiasi pembentukan akar dan meningkatkan jumlahnya. Wospakrik (2008) mengatakan bahwa keberhasilan dalam penggunaan metode kultur jaringan sangat bergantung pada media yang digunakan. Media kultur jaringan tanaman menyediakan tidak hanya unsur hara makro dan mikro, tetapi juga karbohidrat yang pada umumnya berupa gula untuk menggantikan karbon yang biasanya didapat dari atmosfir melalui fotosisntesis. Pemberian air kelapa pada media akan mendorong pertambahan akar bibit anggrek.

Setiap penambahan larutan air kelapa pada media kultur dapat meningkatkan panjang akar pada semua jenis tanaman anggrek (Tabel 4). Rata-rata panjang akar tertinggi terdapat pada perlakuan media MS40, walaupun pada perlakun MS30 terdapat dua jenis anggrek (D. diascolor dan Dendorbium sp) yang memiliki rata-rata panjang akar yang sama seperti perlakuan MS40 $(5.33 \mathrm{~cm})$. Dendrobium sp dan $D$. lineale memiliki rata-rata panjang akar tertinggi $(6.67 \mathrm{~cm})$ dibandingkan dengan jenis anggrek yang lain. Media kultur dengan perlakuan MSO meng- 
hasilkan rata-rata panjang akar paling rendah, namun terdapat satu jenis anggrek (D. discolor) yang memiliki panjang akar sama dengan $D$. lineale pada MS30. Hal ini disebabkan oleh kandungan nutrisi dalam air kelapa yang memacu proses pertumbuhan dan panjang akar pada setiap media perlakuan. Air kelapa mengandung vitamin $\mathrm{C}$, asam nikotinat, asam pantotenat, asam folat, biotin dan riboflavin, yang dapat membantu proses pertumbuhan akar.

Pertumbuhan eksplan secara in vitro dapat ditentukan oleh: genotipe, umur tanaman, keadaan fisiologi tanaman induk, jenis jaringan, fase perkembangan tanaman induk, posisi jaringan pada tanaman induk, ukuran eksplan, musim, perlakuan, dan metode inokulasi (Abbas, 2011). George dan Sherrington (1984) menyatakan beberapa penelitian yang sudah dilakukan memberikan hasil bahwa penambahan air kelapa dapat meningkatkan partumbuhan jaringan yang dikulturkan, seperti mendorong pertumbuhan kalus dan terjadinya morfogenesis.

\section{Karakterisasi molekuler.}

Analisis DNA dilakukan untuk mengetahui dengan pasti suatu tanaman itu berbeda atau tidak secara genetik, karena secara morfologi kemiripannya sulit untuk dibedakan. Penelitian ini bertujuan mengetahui perbedaan genetik lima jenis anggrek lokal Papua berdasarkan penanda RAPD. Analisis molekuler merupakan analisis yang dikerjakan pada tingkat gen maupun ekspresinya yang bertujuan untuk mengetahui keberadaan gen melalui PCR. Analisis keragaman genetik berdasarkan penada RAPD dikembangkan oleh Williams et al., (1990). Analisis ini didasarkan pada amplifikasi DNA secara in vitro dalam reaksi PCR dengan menggunakan primer acak. Teknik RAPD telah banyak diaplikasikan da- lam kegiatan pemuliaan tanaman, antara lain untuk mengetahui keragaman genetik plasma nutfah tanaman padi (Virk et al., 1995).

Polimorfisme pita RAPD yang diamplifikasi pada mesin PCR menggunakan lima jenis primer menghasilkan 25 pita DNA dan sebanyak 13 pita yang polimofik dengan jumlah genotipe masing-masing populasi berkisar dari 23 polimorfisme pita RAPD (Tabel 5). Pita DNA polimorfik tertinggi dihasilkan oleh primer OPA-4, OPA-14, dan OPU-3 (3 pita), sedangkan terrendah pada primer OPA-1 dan OPA-12 (2 pita DNA). Ukuran pita DNA yang teramplifikasi berkisar antara 200 2000 pasang basa (pb). Jumlah pita DNA yang dihasilkan per primer tergantung pada banyaknya situs penempelan dari primer yang digunakan pada genom atau sebaran situs pada genom yang homolog dengan sekuen primer. Semakin banyak situs penempelan semakin banyak jumlah pita yang dihasilkan (Matondang et al., 2001). Penggunaan primer acak dalam analisis RAPD mengakibatkan perlunya tahapan seleksi primer untuk mendeteksi polimorfisme fragmen DNA hasil amplifikasi yang sangat berguna untuk analisis keragaman antar individu tanaman.

Matriks jarak genetik lima jenis anggrek yang diteliti berdasarkan lima primer RAPD disajikan pada Tabel 6. Jarak genetik terbesar terjadi antara anggrek $D$. lineale dengan Dendrobium sp dan $D$. lineale dengan $D$. diascolor (0.40). Jarak genetik yang paling kecil adalah 0.04 terjadi antara $D$. merbelianum-1 dengan D. merbelianum-2. Jenis-jenis anggrek yang memiliki jarak genetik terbesar menunjukkan bahwa kemiripan karakternya lebih rendah dibandingkan dengan yang memiliki jarak genetik paling kecil. Semakin dekat jarak genetik antar individu dalam 
suatu populasi, maka semakin seragam populasi tersebut (Mawikere, 2005). Sebaliknya semakin jauh jarak genetik individu-individu di dalam suatu populasi, maka populasi tersebut mempunyai anggota yang semakin beragam (Pandin, 2000).

Tabel 5. Jenis primer RAPD dan jumlah pita DNA hasil amplifikasi dari 5 jenis anggrek endemik Papua.

\begin{tabular}{lccccc}
\hline No. & Primer & $\begin{array}{c}\text { Segmen } \\
5^{\prime}-3\end{array}$ & $\begin{array}{c}\text { Jumlah Pita } \\
\text { Monomorfik }\end{array}$ & $\begin{array}{c}\text { Jumlah Pita } \\
\text { Polimorfik }\end{array}$ & Total \\
\hline 1. & OPA-1 & CAGGCCCTTC & 3 & 2 & 5 \\
2. & OPA-4 & AATCGGGCTG & 2 & 3 & 5 \\
3. & OPA-12 & TCGGCGATAG & 3 & 2 & 5 \\
4. & OPA-14 & TCTGTGCTGG & 2 & 3 & 5 \\
5. & OPU-3 & CTATGCCGAC & 2 & 3 & 5 \\
\hline \multicolumn{7}{r}{ Total } & 12 & 13 & 25 \\
\hline
\end{tabular}

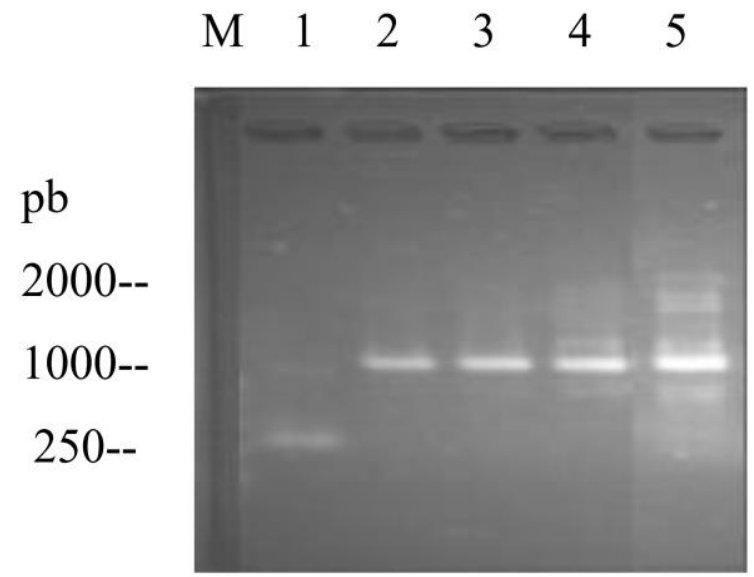

A
$\begin{array}{llllll}M & 1 & 2 & 3 & 4 & 5\end{array}$

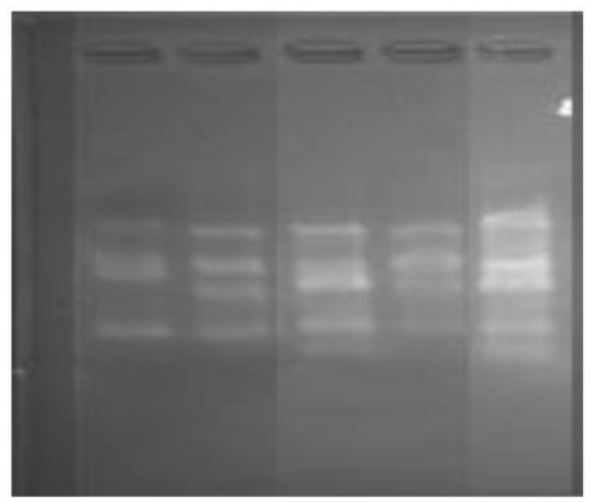

$\mathrm{B}$

Gambar 4. Profil pita DNA hasil amplifikasi primer RAPD. Primer OPA-1 (A) dan primer OPU-3 (B); Marker 1 kb Ladder (M); Jenis anggrek (1-5).

Tabel 6. Matriks distance (Nei's, 1978) diantara lima jenis anggrek endemik Papua berdasarkan 25 fragmen pita DNA dari lima primer RAPD.

\begin{tabular}{lccccc}
\hline \multicolumn{1}{c}{ Jenis Anggrek } & A & B & C & D & E \\
\hline D. merbelianum -1 & 0 & & & & \\
D. merbelianum - 2 & 0.04 & 0 & & & \\
Dendrobium sp & 0.34 & 0.28 & 0 & 0 & \\
D. discolor & 0.34 & 0.28 & 0.08 & 0.40 & 0 \\
D. lineale & 0.34 & 0.28 & 0.40 & 0.40 \\
\hline
\end{tabular}

Keterangan: D.merbelianum-1 (A), D.merbelianum-2 (B), Dendrobium sp (C), D.discolor (D), dan D.lineale (E). 
CASSOWARY - Volume 1 (2): 121 - 132

ISSN : 2614-8900

E-ISSN : 2622-6545

CProgram Pascasarjana Universitas Papua, https://pasca.unipa.ac.id/

Hasil analisis pengelompokan (cluster) pada lima jenis anggrek endemik Papua (Gambar 5) menunjukkan bahwa lima jenis anggrek yang diteliti terbagi menjadi dua kelompok pada koefisien ketidakmiripan 0.53 (perbedaan karakter 53\%). Kelompok 1 adalah D. diascolor dan D. merbelianum-1, sedangkan kelompok 2 adalah $D$. merbelianum-2, Dendrobium sp., dan D. lineale. Pada koefisien ketidakmiripan 0.40 (perbedaaan karakter $40 \%$ ), jenis anggrek pada kelompok 2 mengelompok menjadi 2 kelompok, yaitu Dendrobium sp. dengan $D$. lineale membuat satu kelompok dan $D$. merbelianum 2 mengelompok sendiri. Pada koefisien ketidakmiripan 0.15 (perbedaaan karakter 15\%) masingmasing tanaman mengelompok sendiri berdasarkan jarak genetiknya. Pola pengelompokan ini menunjukkan bahwa masing-masing jenis anggrek memiliki karakteristik yang berbeda, yaitu sebesar $15 \%$ atau memiliki kemiripan karakter sebesar 85\%. Perbedaan karakter yang terjadi dapat disebabkan oleh faktor genetik dan lingkungan tempat tumbuh yang berbeda.

Pada koefisien ketidakmiripan 0.4, D. merbelianum 2 mengelompok terpisah dengan $D$. merbelianum 1 , sedangkan D. merbelianum 1 mengelompok dengan $D$. diascolor. Pengelompokkan ini disebabkan karena $D$. merbelianum 1 memiliki karakter morfologi daun dan bunga yang berbeda bentuk dan warna dengan $D$. merbelianum 2.

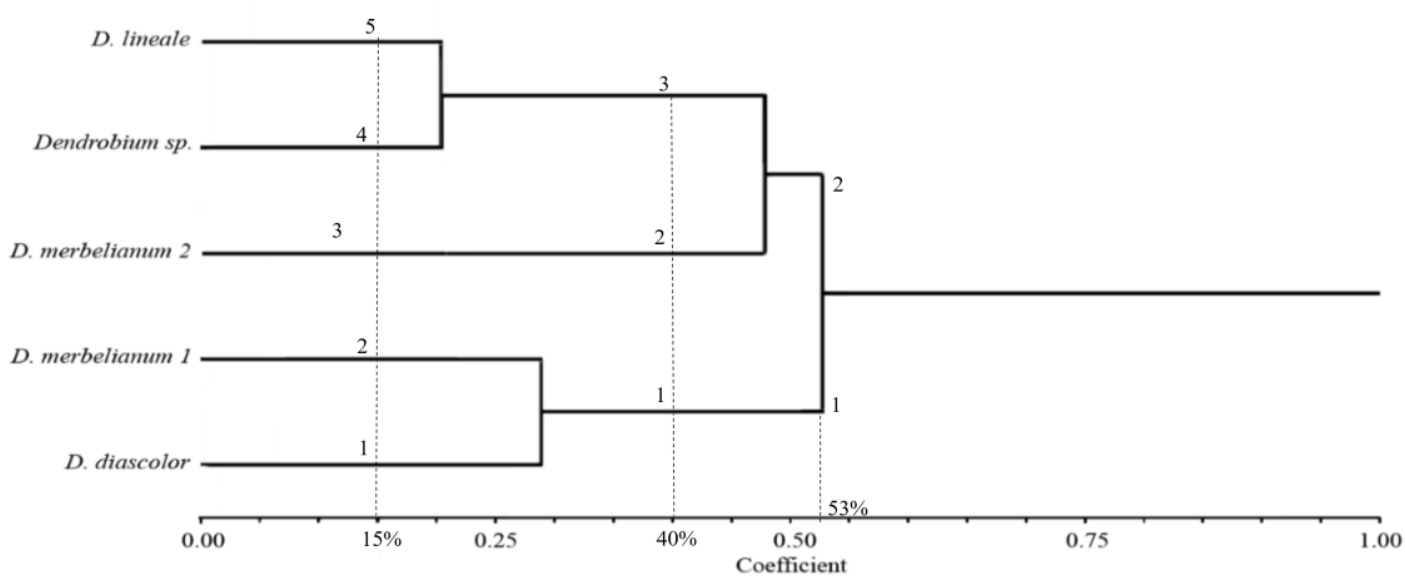

Gambar 5. Dendrogram 5 jenis anggrek endemik Papua hasil analisis klaster pola pita DNA dengan metode UPGMA menggunakan 5 primer acak.

KESIMPULAN

Lima jenis anggrek yang dikulturkan semuanya dapat membentuk planlet. Semua perlakuan media tumbuh yang digunakan dapat menginduksi pertumbuhan dari semua anggrek endemik Papua yang dicobakan. Perlakuan terbaik adalah media MS yang diperkaya air kelapa $40 \%$.
Hasil pengelompokan menggunakan analisis cluster berdasarkan penanda RAPD menunjukkan bahwa lima jenis anggrek endemik Papua yang diuji memiliki perbedaan karakter sebesar $15 \%$ atau memiliki kemiripan karakter sebesar $85 \%$. Jarak genetik yang paling jauh yaitu antara anggrek Dendrobium sp dan D. lineale $(\mathrm{d}=0.4)$. Pada koefisien ketidakmiripan 0.53 
kelima jenis anggrek mengelompok menjadi dua kelompok, yaitu $D$. lineale, Dendrobium sp, D. merbelianum 2 dan D. merbelianum 2, D. diascolor).

\section{UCAPAN TERIMA KASIH}

Pada kesempatan ini penulis menyampaikan terima kasih kepada Bapak Prof. Dr. Ir. Barahima Abass, M.Si sebagai pembimbing utama dan Ibu Dr. Ir Nouke Lenda Mawikere, M.Si sebagai pembimbing kedua, yang telah membimbing dan mengarahkan penulis sehingga Tesis ini dapat diselesaikan. Ucapan terima kasih disampaikan pula kepada Ibu Dr. Ir. Irnanda Djuna, M.Sc, selaku Direktur Program Pascasarjana Unipa dan Bapak Dr. Ir. Ishak Musaad, MP sebagai Ketua Program Studi Ilmu Pertanian, serta bapak/ibu dosen yang telah mengajar dan memberikan ilmu kepada penulis.

\section{DAFTAR PUSTAKA}

Abbas, B. (2011). Prinsip Dasar Teknik Kultur Jaringan. Alvabeta. Bandung.

Darmono, D.W. (2004). Bertanam Anggrek. Penebar Swadaya. Jakarta.

George, O.L. and Sherrington, P.D. (1984). Plant Propagation by Tissue Culture. Hand Book and Directory of Commercial Laboratories. Exegetic Ltd., England. 790p.

Kalimuthu, K.R., Senthikumar, and Vijayakumar, S. (2007). In Vitro Micropropagation of Orchid, Oncidium sp. African Journal of Biotechnology, 6(10):117711174.

Matondang, I., Suharsono, dan Hartana, A. (2001). Analisis Keanekaragaman Kelapa Dalam Asal Maluku Menggunakan Teknik RAPD. Hayati, 8(2):31-34.

Mawikere, N.L. (2005). Plasma Nutfah Kelapa Papua dan Hubungan Ke- kerabatannya dengan Populasi Kelapa Indonesia dan Papua New Guinea Berdasarkan Penanda RAPD. Disertasi Institut Pertanian Bogor. (Tidak Diterbitkan).

Mawikere, N.L., Hartana, A., Guhardja, E., Suharsono, Aswidinnoor, $\mathrm{H}$. (2007). Keanekaragaman dan $\mathrm{Hu}-$ bungan Genetik Plasma Nutfah Kelapa di Kawasan Malesia Timur Berdasarkan Penanda RAPD. Zuriat 18(1): 81-92.

Muller, K. (2005). Keragaman Hayati Tanah Papua. Unipa Press. Manokwari.

Nei, M. (1978). Estimation of Average Heterozigosity and Genetic Distance from Small Number of Individuals. Genetics, 89:583590.

Noertjahyo, J.A. (2002). Anggrek Papua dan Bisnis Gelap. http://64. 203.71.11/kompas-cetak/0307/02 /daerah/309321.htm (12/8/2008).

Pandin, D.S. (2000). Kemiripan Genetik Populasi Kelapa Dalam Mapanget, Tenga, Bali, Palu, dan Sawarna Berdasarkan Penanda RAPD (Random Amplified Polymorphic DNA). Tesis Institut Pertanian Bogor. (Tidak diterbitkan).

Pierik, R.L.M. (1987). In Vitro Culture of Higher Plants. Departement of Horticulture. Agriculture University Waginingan. Martinus Nijhoff Publishers. The Netherland. $344 p$.

Rukmana, H.R. (2000). Budidaya Anggrek Bulan. Penerbit Yayasan Kanisius. Yogyakarta.

Santoso. (2003). Air Kelapa Limbah Penuh Khasiat. http://www.gizi. not/eigibin/berita/fullnews.eig. di-akses pada 25 Januari 2012.

Sulistianingsih, R.Z., Suyanto, A., dan Noer, E.A. (2004). Peningkatan Kualitas Anggrek Dendrobium Hibrida Dengan Pemberian Kol- 
khisin. Jurnal Ilmu Pertanian, 11(1):13-21.

Suryowinoto. (1991). Budidaya Jaringan Terobosan Bermanfaat dalam Bioteknologi. Fakultas Biologi. Universitas Gadjah Mada. Yogyakarta.

Virk, P.S., Newbury, H.J., Jackson, M.T., and Forf - Lioyd, B.V. (1995). The Identification of Duplicate Accessions Within a Rice Germplasm Collection Using RAPD Analysis. Theor. Appl. Genet. 90:1049-1055.

Williams, J.G.K., Kubelik, A.R., Livak, K.J., Rafalski, J.A., and Tingey, S.V. (1990). DNA Polymorphisms Amplified by Arbitrary Primer are Useful as Genetic Marker. Nucleid Acid Research, 18(22): 5631-5635.

Wospakrik, A.H. (2008). Inisiasi dan Proliferasi Tunas Mikro Talas yang Dikulturkan Secara Invitro. Sripsi Mahasiswa Fakultas Pertanian Unipa. (Tidak Diterbitkan).

Zulkarnain. (2009). Kultur Jaringan

Tanaman. Bumi Aksara. Jakarta. 